\title{
Response of planting methods and deficit irrigation on growth and yield attributes of maize under semi-arid conditions
}

\author{
Manzoor $^{*}$, Amir Sohail ${ }^{2}$, Shahzad Ali ${ }^{1}$, Shazma Anwar ${ }^{1}$, Muhammad \\ Owais Khan ${ }^{3}$, Sultan Nawaz ${ }^{3}$, Fawad Ali Shah ${ }^{4}$, Ihtisham Ali ${ }^{1}$, Junaid \\ Iqbal $^{4}$, Junaid Ahmad ${ }^{1}$, Farhan Ahmad ${ }^{1}$, Haq Nawaz ${ }^{1}$ and \\ Muhammad Kefayatullah ${ }^{5}$ \\ 1. Department of Agronomy, The University of Agriculture, Peshawar-Pakistan \\ 2. Department of PBG, The University of Agriculture, Peshawar-Pakistan \\ 3. Department of Soil and Environmental Sciences, The University of Agriculture, Peshawar-Pakistan \\ 4. Department of Horticulture, The University of Agriculture, Peshawar-Pakistan \\ 5. Department of Food Science and Technology, The University of Agriculture, Peshawar-Pakistan \\ *Corresponding author's email: manzoor375351@gmail.com \\ Citation \\ Manzoor, Amir Sohail, Shahzad Ali, Shazma Anwar, Muhammad Owais Khan, Sultan Nawaz, Fawad Ali Shah, \\ Ihtisham Ali, Junaid Iqbal, Junaid Ahmad, Farhan Ahmad, Haq Nawaz and Muhammad Kefayatullah. \\ Response of planting methods and deficit irrigation on growth and yield attributes of maize under semi-arid \\ conditions. Pure and Applied Biology. Vol. 8, Issue 1, pp706-717. http://dx.doi.org/10.19045/bspab.2019.80012

\begin{tabular}{llll}
\hline \hline Received: 01/11/2018 & Revised: 14/01/2019 & Accepted: 16/01/2019 & Online First: 25/01/2019 \\
\hline \hline
\end{tabular}

\section{Abstract}

Due to increasing population the fibers and food demand is increasing and on the other hand the per unit irrigated area water availability is decreasing. The demand of maize is expected to be increase several folds as the population is increasing. Thus, circumstances demand sustainable increased of crop yield per unit area with scare water resources. The research was carried out at Agronomy Research Farm, The University of Agriculture Peshawar, during May 2017.The research was laid out in RCBD with split plot arrangement having 4 replications. Deficit Irrigations (Full irrigation (10 irrigations), one irrigation missing at six leaves stages, twelve leaves stage, flowering stage and grain filling stage) were allotted to main plots, while planting methods (Ridge, Flat and Broadcast)were allotted to sub plots. Deficit irrigations had a significant $(\mathrm{P} \leq 0.05)$ effect on all parameters excluding girth diameter and grain rows ear-1. Full irrigation (10 irrigations) had significantly more leaf area plant ${ }^{-1}\left(6916.90 \mathrm{~cm}^{2}\right)$, grain yield (3352.75 kg ha-1), biological yield $\left(10726.08 \mathrm{~kg} \mathrm{ha}^{-1}\right)$, Stem diameter $(1.98 \mathrm{~cm})$, number of nodes (8.12), ear length $(16.45 \mathrm{~cm})$ and ear height $(87.92 \mathrm{~cm})$. In case of planting methods, ridge planting had significantly higher leaf area plant ${ }^{-1}\left(6422.87 \mathrm{~cm}^{2}\right)$, grain yield $\left(2948.35 \mathrm{~kg} \mathrm{ha}^{-1}\right)$, biological yield $\left(10562.30 \mathrm{~kg} \mathrm{ha}^{-1}\right)$, stem diameter $(1.82 \mathrm{~cm})$, ear length $(15.50 \mathrm{~cm})$ and ear height $(86.10 \mathrm{~cm})$. The interaction of planting methods and deficit irrigations had a significant effect on grain yield and biological yield. Maize grow on ridge method and deficit irrigation (one irrigation missing at six leaves stage produced grain yield (3369 $\left.\mathrm{kg} \mathrm{ha}^{-1}\right)$, ridge and full irrigation had more biological yield (11336 kg $\mathrm{ha}^{-1}$ ) On the basis of the above results it is concluded that in water scare area grow maize on ridge planting method and give deficit irrigation at vegetative stage (one irrigation missing at six leaves stages) inoder to increased water productivity (Efficiency).

Keywords: Deficit irrigation; Growth; Maize; Methods; Planting; Semi-arid; Yield Introduction

Maize (Zea mays L) is widely cultivated in tropical, subtropical and temperate regions 
of the world. It is grown at an altitude of 3300 meters from above sea level at latitude of $50^{\circ}$ north to $40^{\circ}$ south .In 2014 , it was grown on 1168.5 thousand hectares with production of 4944.5 thousand tones and productivity yield of $4317 \mathrm{~kg} \mathrm{ha}^{-1}[1]$. In Khyber Pakhtunkhwa province after wheat crop maize is the subsequent main crop. In major part of the farming system it is used as a feed for animal and staple food in the rural areas of the province, especially at high altitudes. It is also used in industries for making starch, oil, polishes, etc.[2]. During 2014, maize was cultivated on 470.9 thousand hectares in KPK with production of 914.8 thousand tones and yield of $1943 \mathrm{~kg}$ $\mathrm{ha}^{-1}[1]$. Water scarcity, inefficient irrigation system, weed infestation and poor preparation of soil are the main reasons of low production.

Water is a fundamental resource for every forms of life counting plants; but due to inefficient use of water and climate change it availability is declining. One third part of the world is water, out of that the fresh water is existing on only $3 \%$ of it, two-third part of fresh water is locked in ice caps and glaciers while the remaining $3^{\text {rd }}$ part is available for human beings. Presently $70 \%$ of the available fresh water is utilized by agriculture and producing about $40 \%$ of world food necessity. However, at the end of 2025 ,for agriculture we will require $15 \%$ extra water because the population of the world is growing speedily at a rate of $1.5 \%$ which is raising pressure on water resources. In year 2025 the availability of per capita water will be declined to a threshold level of $1000 \mathrm{~m}^{3}$ while the required per capita water is $5660 \mathrm{~m}^{3}[3]$.

In Pakistan agriculture sector is considered as the backbone of economy of the country by contributing about $24 \%$ in GDP [4]. In surface irrigation water losses occurred through deep percolation, leakage losses, seepage losses, evaporation and runoff with an irrigation efficiency of $30-40 \%$. So the deficient irrigation water in critical stages and losses of water are the main factors limiting crop productivity. So, the government encourages farmers to adapt pressurized irrigation system rather than surface irrigation method [5]. Drip irrigation is one of the best irrigation methods in water scare areas, in this method the water is frequently and slowly applied to the root zone of the crop or directly to the land rather than to apply to the whole filed surface. This method also sustains optimum water content in the root zone of crop. But locally the farmers are not adapting pressurized irrigation systems practically. The main reasons for trickle or drip irrigation failure are; high quality availability of water that do not contain soil or sand particles because it block the emitters of the pressurized irrigation system while most of our irrigation water contain soil and sand particles, initially for it installation high investment is needed, required water application pattern similar for its maintenance and operation the farmers had low technical education. In addition to this, presently Pakistan is facing energy shortage and particularly in rural areas the farmers either do not have electricity or the electricity is not available on time for running trickle or drip irrigation system.

Currently researchers and planners had diverted their concentration toward deficit irrigations strategy which has been extensively accepted as important plan for water scare areas [6]. Water productivity is maximized with deficit irrigations, which is the major limiting factor. The target of deficit irrigation is to stabilized yield and improved water productivity [7]. In deficit irrigation the plants are exposed up to certain levels of water stresses either throughout the entire growing season or during a particular period [8] with an expectation that, any yield decrease will be immaterial compare with the gained benefits by utilizing the saved water to irrigated other agriculture crops. [9] USA reported that only $13 \%$ reduction in grain yield of wheat occurred with the application of deficit irrigation up to $60 \%$. However, economic impact of yield decline and 
response of crop to water are the important information required for efficient utilization of deficit irrigation. [10] Reveled that in water deficit areas the important thing for farmers is to increased water productivity rather than to increase the yield of crop and maximum area can be irrigated with water saved by deficit irrigations.

Deficit irrigations gradually affected water productivity, generally with sufficient yield, the farmer get high economic benefits and income due to yield stabilization in association with rain fed farming. In contrast with full irrigation, deficit irrigation decreased the risk of certain diseases like fungus that occurred in high humidity.

In order to make water saving techniques practicable for farmer in Pakistan and obtaining maximum water productivity, crop should be grown under a specific level of deficit irrigations and deficit irrigations should be given at a specific stages of the crops because each crop has its own critical limits up to which it can tolerate water stress, but after that limits the losses in the yield and growth of the crop starts, [7]. The photosynthesis rate is significantly decreasing with sever and moderate water stress but the mild water stress had a less effect on photosynthesis [11]. Soil moisture conservation techniques in combination with deficit irrigation and best sowing techniques can overcome on the grain yield losses by deficit irrigations.

Against the less water productivity in the conventional flat planting method with surface irrigation method, many developing countries of the world had taken initiative to shift their planting method to ridge planting method. In addition to saving a large quantity of water, it also helps to boost the productivity of crop. In ridge planting method irrigation water drain quickly from its surface, which helps to minimized the chances of de-oxygenation in upper rooting zone of the crops by avoiding water pond in the field.
Due to increasing population the fibers and food demand is increasing and on the other hand the per unit irrigated area water availability is decreasing. The demand of maize is expected to be increase several folds as the population is increasing. Thus, circumstances demand sustainable increased of crop yield per unit area with scare water resources. Farmers are well skilled in conventional agronomic practices and traditional irrigation method (flood irrigation method) but cannot adopted latest irrigation technologies due to their low economic situation, deficiency of technical experience and education of farmers for maintaining and operating of the irrigation system, unavailability of economical and local parts of efficient irrigation system. In the light of the farmer's education, farming experience and financial condition, suitable planting method and deficit irrigation method can be a best alternative for saving water. These technologies are practically examined separately by scientists; however, the combined effect of planting method with deficit irrigations has not yet investigated. This study was carried out to examine the effect of planting methods and deficit irrigations on yield and yield components of maize.

\section{Materials and methods}

The experiment was conducted at Agronomy Research Farm, The University of Agriculture Peshawar, located at $34.02^{0}$ $\mathrm{N}$ and $71.48^{\circ} \mathrm{E}$ with an elevation of 359 meters above the sea level during May 2017. According to 30 year climatic data Peshawar is warm to hot, semi-arid and subtropical climate with mean annual temperature of $22.7{ }^{\circ} \mathrm{C}\left(72.9^{\circ} \mathrm{F}\right)$ and with annual rainfall of $445 \mathrm{mmof}$ which $42 \%$ was received during the three month duration (February - April)(Figure 1).The weather condition of The Agriculture University Peshawar during the experimental period is shown (Figure 2).

The experimental location soil was sandy loam, slightly alkaline, low in organic carbon, non-saline with high available $\mathrm{K}$, 
medium $\mathrm{P}$ and low $\mathrm{N}$ content. The permanent wilting point (PWP) and field capacity (FC) decreased slightly with depth (Table 1).

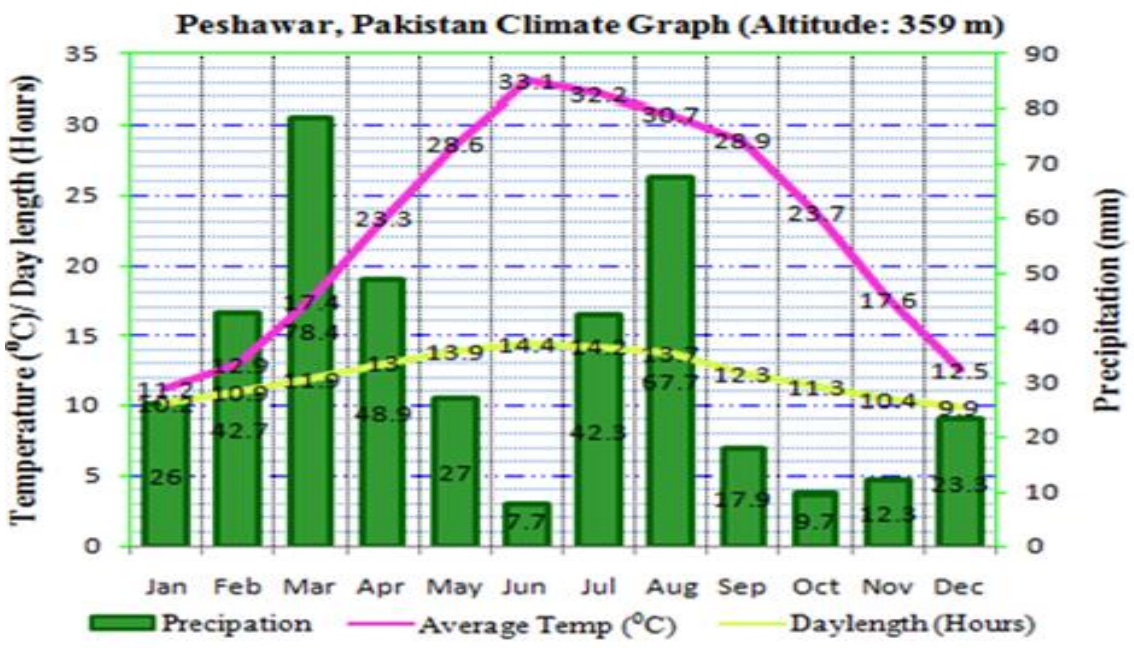

Figure 1. Thirty years climatic data of Peshawar

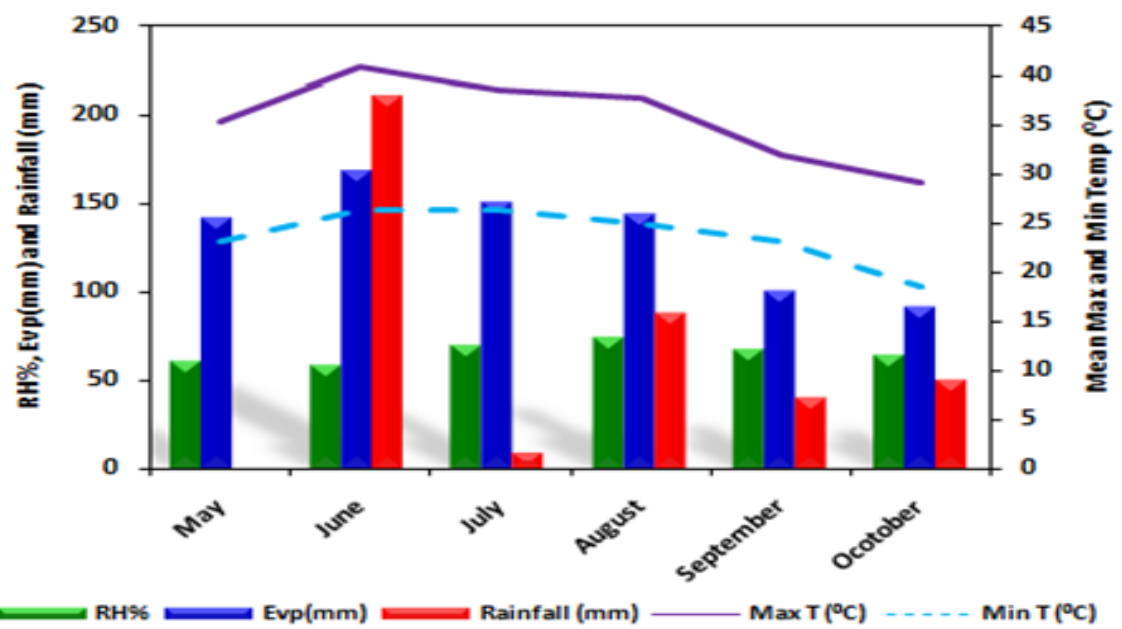

Figure 2. Weather data of the University of Agriculture Peshawar during entire experimental duration

Table 1. Basic soil characteristics at $0-15 \mathrm{~cm}$ soil depth

\begin{tabular}{|c|c|}
\hline Soil characteristics & Soil depth $(\mathbf{c m}) \mathbf{0 - 1 5}$ \\
\hline Soil texture & S1 \\
\hline Sand (\%) & $60.1 \pm 3.6$ \\
\hline Silt (\%) & $33.0 \pm 2.2$ \\
\hline Clay (\%) & $6.9 \pm 0.9$ \\
\hline Bulk density $\left(\mathrm{Mg} \mathrm{m}^{-3}\right)$ & $1.69 \pm 0.06$ \\
\hline FC & $15.3 \pm 2.9$ \\
\hline PWP & $7.64 \pm 1.1$ \\
\hline $\mathrm{pH}$ & $8.3 \pm 0.4$ \\
\hline EC (dS m $\left.{ }^{-1}\right)$ & $10.3 \pm 0.03$ \\
\hline Organic carbon $(\%)$ & $0.29 \pm 0.06$ \\
\hline Available N $\left(\mathrm{Kg} \mathrm{ha}^{-1}\right)$ & $88.4 \pm 9.6$ \\
\hline Available P $\left(\mathrm{Kg} \mathrm{ha}^{-1}\right)$ & $15.6 \pm 2.5$ \\
\hline Available K $\left(\mathrm{Kg} \mathrm{ha}^{-1}\right)$ & $55.0 \pm 9.6$ \\
\hline
\end{tabular}


The experiment was laid out in randomize complete block design (RCBD) with split plot having 4 replications. Deficit Irrigations (Full irrigation (10 irrigations), one irrigation missing at six leaves stages, one irrigation missing at twelve leaves stage, one irrigation missing at flowering stage and one irrigation missing at grain filling stage)were allotted to main plots, while planting methods(Ridge ,Flat and
Broadcast)was allotted to sub plots. The size of sub plot was $12.25 \mathrm{~m}^{2}(3.5 \mathrm{~m} \times 3.5$ $\mathrm{m})$. Each subplot was consist of 5 rows having $70 \mathrm{~cm}$ row-to-row and $20 \mathrm{~cm}$ plantto-plant distance. The recommended rate of NPK (120-60-0 $\mathrm{kg} \mathrm{ha}$ ha $^{-1}$ was applied uniformly to all plots. Full $\mathrm{P}$ and half $\mathrm{N}$ was at the time of sowing and half $\mathrm{N}$ was applying at five leaves stage (Table 2).

Table 2. Schematic diagram of deficit irrigations at different vegetative and reproductive growth stages of maize crop

\begin{tabular}{|c|c|c|c|c|r|r|}
\hline \multicolumn{2}{|c|}{ Required Irrigations } & \multicolumn{5}{|c|}{ Irrigations Management } \\
\hline No. of Irrigations & Growth stages & D $_{\mathbf{0}}$ & $\mathbf{D}_{\mathbf{1}}$ & $\mathbf{D}_{\mathbf{2}}$ & $\mathbf{D}_{\mathbf{3}}$ & D $_{\mathbf{4}}$ \\
\hline $1^{\text {st }}$ Irrigation & At sowing time & $\checkmark$ & $\checkmark$ & $\checkmark$ & $\checkmark$ & $\checkmark$ \\
\hline $2^{\text {nd }}$ Irrigation & V1 (First leaf) & $\checkmark$ & $\checkmark$ & $\checkmark$ & $\checkmark$ & $\checkmark$ \\
\hline $3^{\text {rd }}$ Irrigation & V3 (Three leaves) & $\checkmark$ & $\checkmark$ & $\checkmark$ & $\checkmark$ & $\checkmark$ \\
\hline $4^{\text {th }}$ Irrigation & V6 (Six leaves) & $\checkmark$ & $\times$ & $\checkmark$ & $\checkmark$ & $\checkmark$ \\
\hline $5^{\text {th }}$ Irrigation & V9 (Nine leaves) & $\checkmark$ & $\checkmark$ & $\checkmark$ & $\checkmark$ & $\checkmark$ \\
\hline $6^{\text {th }}$ Irrigation & V12 (Twelve leaves) & $\checkmark$ & $\checkmark$ & $\times$ & $\checkmark$ & $\checkmark$ \\
\hline $7^{\text {th }}$ Irrigation & R0 (Anthesis stage) & $\checkmark$ & $\checkmark$ & $\checkmark$ & $\times$ & $\checkmark$ \\
\hline $8^{\text {th }}$ Irrigation & R1 (Silking stage) & $\checkmark$ & $\checkmark$ & $\checkmark$ & $\checkmark$ & $\checkmark$ \\
\hline $9^{\text {th }}$ Irrigation & R2-R3 (Blister and Milk stage) & $\checkmark$ & $\checkmark$ & $\checkmark$ & $\checkmark$ & $\times$ \\
\hline $10^{\text {th }}$ Irrigation & R4 ( Dough stage) & $\checkmark$ & $\checkmark$ & $\checkmark$ & $\checkmark$ & $\checkmark$ \\
\hline
\end{tabular}

Note: D0= Full irrigation (10 irrigations), D1= Deficit Irrigation (one irrigation missing at six leaves stages), D2= Deficit Irrigation (one irrigation missing at twelve leaves stage), D3= Deficit Irrigation (one irrigation missing at flowering stage) and D4= Deficit Irrigation (one irrigation missing at grain filling stage)

\section{Experimental and data recording procedure}

For stem diameter, two central rows from each subplot was selected and measure the stem diameter with the help of verniar calipar and then averaged stem diameter was recorded. After harvesting selected ten plants from each subplot and counted the number of nods per plant and then take its average. Data regarding leaf area was calculated in $\mathrm{cm}^{2}$ by selected randomly three plants in each sub plot with help of leaf area meter (CI-202, USA) [12].Five plants were selected randomly from each sub plot and then measured the height from ground level to the shank of the ear with the help of meter rod and then fined the average. After harvesting ear length $(\mathrm{cm})$ of ten ears randomly selected were measured with measuring tape. After harvesting of maize crop ten ears were randomly selected and their diameters were measured with measuring tape. After harvesting number of rows ear ${ }^{-1}$ was recorded by selecting three ears randomly at each plot, counted their number of rows and then find average.

While grain yield of maize was calculated by harvest five rows, the ears was husked, dried and dehelled. Grain yield was recorded on plot $^{-1}$ basis and then converted into $\mathrm{kg} \mathrm{ha}^{-1}$ by using the following formula;

$$
\text { Gain yield }\left(\mathrm{kg} \mathrm{ha}^{-1}\right)=\frac{\text { Grain yield }(4 \text { rows })}{\mathrm{R} \text { - Length }(\mathrm{m}) \times \mathrm{R}-\mathrm{R} \text { distance }(\mathrm{m}) \times \text { No. of rows harvested }} \times 10000
$$


For biomass yield, four central rows of each subplot was harvested, sun dried, weighed and converted into $\mathrm{kg} \mathrm{ha}^{-1}$.

Biological yield $\left(\mathrm{kg} \mathrm{ha}^{-1}\right)=\frac{\text { Biological yield }(4 \text { rows })}{\text { R- Length }(\mathrm{m}) \times \mathrm{R}-\mathrm{R} \text { distance }(\mathrm{m}) \times \text { No. of rows harvested }} \times 10000$

\section{Statistical analysis}

The analysis of variance procedure was followed according to RCBD with split plot arrangement. Means was compared using least significant differences (LSD) test at $\mathrm{P} \leq 0.05$ upon significant $\mathrm{F}$ - test [13].

\section{Results and discussion}

Stem diameter (cm)

Statistical analysis of the data (Table 3)showed that stem diameter $(\mathrm{cm})$ of maize was significantly $(\mathrm{P} \leq 0.05)$ affected by deficit irrigation(Table 3).The effect of planting methods on stem diameter was significant $(\mathrm{P} \leq 0.05)$. The interaction of deficient irrigation and planting methods had a non-significant effect on stem diameter $(\mathrm{cm})$. More stem diameter (1.98 $\mathrm{cm})$ of maize was recorded from full irrigation (10 irrigations). The treatment of deficit irrigation (one irrigation missing at grain filling stage and one irrigation missing at flowering stage) ranked $2^{\text {nd }}$ and $3^{\text {rd }}$ with Stem diameter $(1.79$ and $1.75 \mathrm{~cm})$ respectively. Less stem diameter $(1.23 \mathrm{~cm})$ was observed from deficit irrigation (one irrigation missing at twelve leaves stage). Stem diameter is decrease when maize received stress in vegetative stage due to high evapotranspiration rat and low photosynthetic rate. $[14,15]$ reported that stem thickness was increased with water. Maximum stem diameter $(1.82 \mathrm{~cm})$ was recorded from ridge planting method, followed by flat planting method had stem diameter $(1.57 \mathrm{~cm})$. Minimum stem diameter $(1.32 \mathrm{~cm})$ was observed from broadcasting planting method. In ridge planting method the soil environment is good and well aerated which help in deep root penetration in the soil and more uptakes of nutrients, increased photosynthetic rate, so resulted in more stem thickness. $[16,17]$ reported that stem thickness was high in ridge planting method as compare to broadcasting method.

\section{Number of nodes plant ${ }^{-1}$}

Number of nodes plant ${ }^{-1}$ was significantly $(\mathrm{P} \leq 0.05)$ affected by deficit irrigations (Table 3). The effect of planting methods on nodes plant ${ }^{-1}$ of maize was nonsignificant. The interaction of deficit irrigations and planting methods on nodes plant $^{-1}$ of maize was non-significant. Maximum number of nodes $\operatorname{plant}^{-1}(8.12)$ was observed from Full irrigation (10 irrigations). The treatment of deficit irrigation (one irrigation missing at grain filling stage and one irrigation missing at flowering stage) ranked $2^{\text {nd }}$ and $3^{\text {rd }}$ with nodes plant $^{-1}(7.73$ and 7.71$)$ respectively. Minimum number of nodes plant $^{-1}(6.46)$ was observed from deficit irrigation (one irrigation missing at twelve leaves stage).When more water was available to plant it observed more nutrients by roots so produced more nods plant $^{-1}$. [18, 19] reported that nods plant ${ }^{-1}$ was decreased when plant was under stress in vegetative stage.

\section{Leaf area plant ${ }^{-1}\left(\mathrm{~cm}^{2}\right)$}

Data concerning leaf area plant $^{-1}$ was significantly $(\mathrm{P} \leq 0.05)$ affected by deficit irrigation (Table 3). The planting methods had a significantly $(\mathrm{P} \leq 0.05)$ affected leaf area plant $^{-1}$ of maize. The interaction of deficit irrigation and planting methods for leaf area plant $^{-1}$ was non-significant. The treatment deficit irrigation indicated that Highest leaf area plant ${ }^{-1}\left(6916.90 \mathrm{~cm}^{2}\right)$ of maize was recorded from full irrigation (10 irrigations) followed by deficit irrigations (one irrigation missing at grain filling stage) $\left(6469.21 \mathrm{~cm}^{2}\right)$ and (one irrigation missing at flowering stage) $\left(6339.62 \mathrm{~cm}^{2}\right)$ ranked $2^{\text {nd }}$ and $3^{\text {rd }}$. Lowest leaf area plant $^{-1}$ $\left(5024.53 \mathrm{~cm}^{2}\right)$ was observed from deficit irrigation (one irrigation missing at twelve leaves stages). This could be due to the more availability of water and nutrients to the plants in vegetative stage thus increased 
leaf area per plant, water stress in vegetative stage decreased leaf area per plant due to more transpiration from plant canopy and evaporation from the soil surface. $[20,21]$ investigated that leaf area per plant is decreased by water stress in vegetative stages. The treatment planting methods (ridge Planting) showed more leaf area plant ${ }^{-1}\left(6422.87 \mathrm{~cm}^{2}\right)$, followed by flat planting method ranked $2^{\text {nd }}$ with leaf area plant $^{-1}\left(5957.54 \mathrm{~cm}^{2}\right)$. Less leaf area plant ${ }^{-1}$ $\left(5536.24 \mathrm{~cm}^{2}\right)$ of maize was recorded from planting method (broadcasting planting). In ridge planting method more nutrients is available to the root and also more space is available to the plant canopy so plants produce more number of leaves and leaf area thus increased leaf area per plant. [12, 22,23 ] reported that more leaf area per plant is produced when maize is grown in ridge planting method.

\section{Ear height (cm)}

Data show that ear height $(\mathrm{cm})$ of maize was significantly $(\mathrm{P} \leq 0.05)$ affected by deficit irrigation (Table 3). Planting methods had significantly $(\mathrm{P} \leq 0.05)$ affected ear height of maize. The interaction of deficient irrigation and planting methods had a non-significant effect on ear height $(\mathrm{cm})$. More ear height $(87.92 \mathrm{~cm})$ was recorded from full irrigation (10 irrigations). The treatment of deficit irrigation (one irrigation missing at grain filling stage and one irrigation missing at flowering stage) ranked $2^{\text {nd }}$ and $3^{\text {rd }}$ hadear height of $(85.33$ and $83 \mathrm{~cm})$ respectively. While less ear height $(72.67$ $\mathrm{cm})$ was observed from deficit irrigation (one irrigation missing at six leaves stage). Water stress in vegetative stage produced stunted maize plant due to high evapotranspiration rat and low photosynthetic rate, so ear was produced near the ground surface.[24-26] reported the same result that deficiency of water before reproductive stage produce ear at low height from the ground. Maximum ear height $(86.10 \mathrm{~cm})$ were recorded from planting method (ridge planting), followed by flat planting method had ear height $(82.60 \mathrm{~cm})$. Minimum ear height $(75.70$ $\mathrm{cm})$ of maize was recorded from broadcasting planting method. In ridge planting method more water and nutrients is available to the plant also the soil ph, drainage and aeration was good so plant height is high so bear ear at more height from the ground. [22, 27] reported that ridge planting method produced ear at more height from the ground.

\section{Ear length (cm)}

Analysis of the data showed that deficit irrigation had a significant $(\mathrm{P} \leq 0.05)$ effect on ear length $(\mathrm{cm})$ (Table 3$)$. The effect of planting method on ear length of maize was significant $(\mathrm{P} \leq 0.05)$. The interaction of deficit irrigations and planting methods had a non-significant effect on ear length $(\mathrm{cm})$. Maximum ear length $(16.45 \mathrm{~cm})$ was observed from full irrigation (10 irrigations), followed by deficit irrigation (one irrigation missing at six leaves stages and one irrigation missing at twelve leaves stages) ranked $2^{\text {nd }}$ and $3^{\text {rd }}$ hadear length $(15.99$ and $15.60 \mathrm{~cm})$ respectively. Minimum ear length $(12.78 \mathrm{~cm})$ was observed from deficit irrigation (one irrigation missing at grain filling stage).Ear length was decreased when plant not receiving enough water in reproductive stage. $[11,15,28]$ reported that water stress in reproductive stage decreased ear length of maize due to low photosynthetic rat and high evapotranspiration rate. Maximum ear length $(15.50 \mathrm{~cm})$ of maize was recorded from ridge planting method, followed by flat planting method had ear length (14.84 $\mathrm{cm})$. Minimum ear length $(14.08 \mathrm{~cm})$ of maize was recorded from planting method(broadcasting planting). The soil was compact and less nutrient, water and space was available for root of maize plant in broadcast planting method, which resulted in less penetration of root in soil and less absorption of water and nutrients, so produced small ear. $[23,29]$ reported that ear length was high in ridge planting method. 
Table 3. Effect of planting methods and deficit irrigations on stem diameter $(\mathrm{cm})$, nodes plant $^{-1}$, leaf area plant ${ }^{-1}\left(\mathrm{~cm}^{2}\right)$, ear height $(\mathrm{cm})$ and ear length $(\mathrm{cm})$ of maize

\begin{tabular}{|c|c|c|c|c|c|c|}
\hline \multicolumn{2}{|c|}{ Treatments } & $\begin{array}{c}\text { Stem } \\
\text { diameter }(\mathrm{cm})\end{array}$ & $\begin{array}{l}\text { Nodes } \\
\text { plant }^{-1}\end{array}$ & $\begin{array}{c}\text { Leaf area } \\
\text { plant }^{-1}\left(\mathrm{~cm}^{2}\right)\end{array}$ & $\begin{array}{c}\text { Ear height } \\
(\mathrm{cm})\end{array}$ & $\begin{array}{c}\text { Ear length } \\
(\mathrm{cm})\end{array}$ \\
\hline \multirow{5}{*}{$\begin{array}{c}\text { Deficit } \\
\text { irrigations }\end{array}$} & D0 & $1.98 \mathrm{a}$ & $8.12 \mathrm{a}$ & $6916.90 \mathrm{a}$ & $87.92 \mathrm{a}$ & $16.45 \mathrm{a}$ \\
\hline & D1 & $1.30 \mathrm{~d}$ & $6.54 \mathrm{~b}$ & $5110.83 \mathrm{c}$ & $72.67 \mathrm{c}$ & $15.99 \mathrm{~b}$ \\
\hline & D2 & $1.23 \mathrm{~d}$ & $6.46 \mathrm{~b}$ & $5024.53 \mathrm{c}$ & 78.42 bc & $15.60 \mathrm{c}$ \\
\hline & D3 & $1.55 \mathrm{c}$ & $7.71 \mathrm{a}$ & $6339.62 \mathrm{~b}$ & $83.00 \mathrm{ab}$ & $13.20 \mathrm{~d}$ \\
\hline & D4 & $1.79 \mathrm{~b}$ & $7.73 \mathrm{a}$ & $6469.21 \mathrm{~b}$ & $85.33 \mathrm{a}$ & $12.78 \mathrm{e}$ \\
\hline & $\operatorname{LSD}_{(\mathbf{0 . 0 5})}$ & 0.0338 & 0.154 & 123.736 & 1.677 & 0.113 \\
\hline \multirow{4}{*}{$\begin{array}{l}\text { Planting } \\
\text { methods }\end{array}$} & RM & $1.82 \mathrm{a}$ & 7.57 & $6422.87 \mathrm{a}$ & $86.10 \mathrm{a}$ & $15.50 \mathrm{a}$ \\
\hline & FM & $1.57 \mathrm{~b}$ & 7.27 & $5957.54 \mathrm{~b}$ & $82.60 \mathrm{~b}$ & $14.84 \mathrm{~b}$ \\
\hline & BM & $1.32 \mathrm{c}$ & 7.10 & $5536.24 \mathrm{c}$ & $75.70 \mathrm{c}$ & $14.08 \mathrm{c}$ \\
\hline & $\operatorname{LSD}_{(0.05)}$ & 0.0241 & Ns & 80.870 & 0.707 & 0.109 \\
\hline $\mathbf{D} \times \mathbf{P M}$ & $\mathbf{L S D}_{(0.05)}$ & Ns & Ns & Ns & Ns & Ns \\
\hline
\end{tabular}

Note: D0= Full irrigation (10 irrigations),D1= Deficit Irrigation (one irrigation missing at six leaves stages),D2= Deficit Irrigation (one irrigation missing at twelve leaves stage),D3= Deficit Irrigation (one irrigation missing at flowering stage),D4= Deficit Irrigation (one irrigation missing at grain filling stage) and RM= Ridge planting method, FM= Flat planting method, BM= Broadcast planting method. NS-non-significant; LSD-least significant difference.

\section{Ear diameter (cm)}

Data revealed that deficit irrigation and planting methods had a non-significant effect on ear diameter (cm) (Table 4). The effect of planting method on ear diameter of maize was non-significant. The interaction of deficit irrigation and planting methods had a non-significant effect on ear diameter. Maximum ear diameter was recorded from Full irrigation (10 irrigations) $(3.96 \mathrm{~cm})$ and minimum ear diameter was observed from deficit irrigation (one irrigation missing at grain filling stage) $(3.69 \mathrm{~cm})$.

\section{Grain row ear ${ }^{-1}$}

Statistical analysis of the data revealed that grain row per ear was not significantly affected by deficit irrigation (Table 4). The planting method had a non-significant effect on grain row per ear of maize. The interaction of deficit irrigation and planting methods on grain row per ear of maize was non-significant. Generally 11-12 grain row per ear were recorded when maize was sown on different planting methods.

\section{Grain yield (kg ha-1)}

Statistical analysis of the data revealed that grain yield was significantly $(\mathrm{P} \leq 0.05)$ affected by deficit irrigation (Table 4). The planting methods has significantly $(\mathrm{P} \leq$ 0.05 ) affected grain yield of maize. The interaction of deficit irrigation and planting methods for grain yield was nonsignificant. Maximum grain yield $(3392 \mathrm{~kg}$ $\mathrm{ha}^{-1}$ ) was harvested from treatment of Full irrigation (10 irrigations) of maize crop. The treatment of deficit irrigation (Nine irrigations but one irrigation was missing at six leaves stages) has produced grain yield (3229 $\mathrm{kg} \mathrm{ha}^{-1}$ ) followed by grain yield $\left(3167 \mathrm{~kg} \mathrm{ha}^{-1}\right)$ from treatment of nine irrigations but one irrigation was missing at 12 leaves stage of maize crop. The treatment (nine irrigations but one irrigation was missing at flowering stage) has showed grain yield of $2417 \mathrm{~kg} \mathrm{ha}^{-1}$. Minimum grain yield $\left(2221 \mathrm{~kg} \mathrm{ha}^{-1}\right)$ was recorded from application of nine irrigation but one irrigation was missing at grain filling stage of maize crop. This reveals a decrease of $3.70 \%, 5.53 \%, 27.90 \%$ and $33.75 \%$ in grain yield harvested from treatments deficit irrigation(one irrigation missing at six leaves stages, one irrigation missing at twelve leaves stage, one irrigation missing at flowering stage and one irrigation missing at grain filling stage) respectively as compared with Full irrigation (10 irrigations). The highest grain production from application of Full irrigation (application of 10 irrigations at different 
growth stages) has ensured availability of water for utilization of maize crop. The application of full/recommended irrigations has compensated evapotranspiration losses during peak temperature ranges in summer season. The application of full/recommended irrigations has facilitated the mineralization process in soil and uptake of nutrients by maize plants. The highest vegetative growth was ensured due to application of full/recommended irrigations which more availability of water and nutrients to the plants in vegetative and reproductive stages of maize crop, water stress in reproductive stage decreased grain yield. $[11,25,30]$ reported that grain yield of maize was decreased by water stress at reproductive stages. The highest grain yield $2972 \mathrm{~kg} \mathrm{ha}^{-1}$ was recorded from planting method (ridge planting). The planting method (flat planting) was ranked $2^{\text {nd }}$ with grain yield $2902 \mathrm{~kg} \mathrm{ha}^{-1}$. The lowest grain yield $\left(2782 \mathrm{~kg} \mathrm{ha}^{-1}\right)$ was harvested from treatment of broadcast planting method. This reveals an increase of $5.99 \%$ and $4.34 \%$ in grain yield from planting methods (Ridge and Flat planting method) respectively as compared with broadcast planting method. Ridge planting had more aeration and good drainage system which provided good soil condition for proper root development, ensuring efficient use of nutrients and irrigation for proper growth and development. Ridge planting method also reduced soil crust problem which help in root penetration and root development, while broadcast and flat planting method the crust problem is more, which restricted root growth and penetration. [17, 23, 29, 31]reported more grains yield in ridge planting method as compared to broadcast and line planting method. In figure 3 showed that interaction of deficit irrigation and planting methods had a significant effect on grain yield of maize.

\section{Biological yield ( $\mathrm{kg} \mathrm{ha}^{-1}$ )}

Analysis of the data showed that deficit irrigation had a significant $(\mathrm{P} \leq 0.05)$ effect on biological yield (Table 4). The effect of planting method on biological yield was significant $(\mathrm{P} \leq 0.05)$. The interaction of deficit irrigation and planting methods had non-significant effect on biological yield of maize. Maximum biological yield (10792 $\mathrm{kg} \mathrm{ha}^{-1}$ ) was observed from Full irrigation (10 irrigations) followed by deficit irrigation (one irrigation missing at flowering stage and one irrigation missing at grain filling stage) (10559 and $10492 \mathrm{~kg}$ $\left.\mathrm{ha}^{-1}\right)$. This reveals a decrease of $11.16 \%$, $7.31 \%, 1.56 \%$ and $2.18 \%$ in biological yield from treatments deficit irrigation(one irrigation missing at six leaves stages, one irrigation missing at twelve leaves stage, one irrigation missing at flowering stage and one irrigation missing at grain filling stage) respectively as compared with Full irrigation (10 irrigations). Minimum biological yield $\left(9529 \mathrm{~kg} \mathrm{ha}^{-1}\right)$ was observed from treatment of deficit irrigation (one irrigation missing at six leaves stages).The application of full/recommended irrigations has compensated evapotranspiration losses during peak temperature ranges in summer season. The application of full/recommended irrigations has facilitated the mineralization process in soil and uptake of nutrients by maize plants. The highest vegetative growth was ensured due to application of full/recommended irrigations which more availability of water and nutrients to the plants in vegetative and reproductive stages of maize crop, water stress in vegetative stage decreased biological yield. This shows that availability of water in vegetative stages enhances the photosynthesis rate which resulted in more vegetative growth and biological yield of maize. Greaves and [15, 26,28 and reported that deficit irrigation in vegetative stages effected biological yield as compare to deficit irrigation in reproductive stages which effected grain yield. Highest biological yield (10602 kg $\mathrm{ha}^{-1}$ ) was recorded from ridge planting method, Flat planting method ranked $2^{\text {nd }}$ (10155 $\left.\mathrm{kg} \mathrm{ha}^{-1}\right)$ and broadcasting planting method produced lowest biological yield $\left(10032 \mathrm{~kg} \mathrm{ha}^{-1}\right)$. This reveals an increase of 
$19.08 \%$ and $4.43 \%$ in biological yield of maize from planting methods (Ridge and Flat planting methods) respectively as compared with broadcast planting method. This is due to the fact that ridge planting method provided good soil environment like soil porosity and drainage system for root penetration and nutrients uptake, thus reduce lodging. [16, 17, 22, 31, 32] reported that ridge planting method produced high biological yield. In figure 3 showed that interaction of deficit irrigation and planting methods had a significant effect on biological yield of maize.

Table 4. Effect of planting methods and deficit irrigations on ear diameter $(\mathrm{cm})$, grain row ear-1, grain yield $\left(\mathrm{Kg} \mathrm{ha}^{-1}\right)$, Grain yield $\left(\mathrm{Kg} \mathrm{ha}^{-1}\right)$ and biological yield $\left(\mathrm{Kg} \mathrm{ha}^{-1}\right)$ of maize

\begin{tabular}{|c|c|c|c|c|c|}
\hline \multicolumn{2}{|c|}{ Treatments } & $\begin{array}{l}\text { Ear diameter } \\
\text { (cm) }\end{array}$ & $\begin{array}{c}\text { Grain row } \\
\text { per ear }\end{array}$ & $\begin{array}{c}\text { Grain yield } \\
\left(\mathrm{Kg} \mathrm{ha}^{-1}\right)\end{array}$ & $\begin{array}{c}\text { Biological yield } \\
\left(\mathrm{kg} \mathrm{ha}^{-1}\right)\end{array}$ \\
\hline \multirow{5}{*}{$\begin{array}{c}\text { Deficit } \\
\text { irrigations }\end{array}$} & D0 & 3.96 & 12.00 & $3392 \mathrm{a}$ & $10792 \mathrm{a}$ \\
\hline & D1 & 3.94 & 11.50 & $3229 \mathrm{~b}$ & $9529 \mathrm{c}$ \\
\hline & D2 & 3.88 & 11.33 & $3167 \mathrm{~b}$ & $9942 \mathrm{~b}$ \\
\hline & D3 & 3.74 & 11.42 & $2417 \mathrm{c}$ & $10559 \mathrm{a}$ \\
\hline & D4 & 3.69 & 11.25 & $2221 \mathrm{~d}$ & $10492 \mathrm{a}$ \\
\hline & $\operatorname{LSD}_{(0.05)}$ & Ns & Ns & 12.382 & 76.570 \\
\hline \multirow{4}{*}{$\begin{array}{l}\text { Planting } \\
\text { methods }\end{array}$} & RM & 4.00 & 11.65 & $2972 \mathrm{a}$ & $10602 \mathrm{a}$ \\
\hline & FM & 3.85 & 11.50 & $2902 \mathrm{~b}$ & $10155 \mathrm{~b}$ \\
\hline & BM & 3.68 & 11.35 & $2782 \mathrm{c}$ & $10032 \mathrm{~b}$ \\
\hline & $\operatorname{LSD}_{(0.05)}$ & Ns & Ns & 6.100 & 40.288 \\
\hline $\mathbf{D} \times \mathbf{P M}$ & $\mathbf{L S D}_{(0.05)}$ & Ns & Ns & 30.495 & 201.441 \\
\hline
\end{tabular}

Note: D0= Full irrigation (10 irrigations), D1= Deficit Irrigation (one irrigation missing at six leaves stages),D2= Deficit Irrigation (one irrigation missing at twelve leaves stage),D3= Deficit Irrigation (one irrigation missing at flowering stage),D4= Deficit Irrigation (one irrigation missing at grain filling stage) and RM= Ridge planting method, FM= Flat planting method, BM= Broadcast planting method. NS-non-significant; LSD-least significant difference.

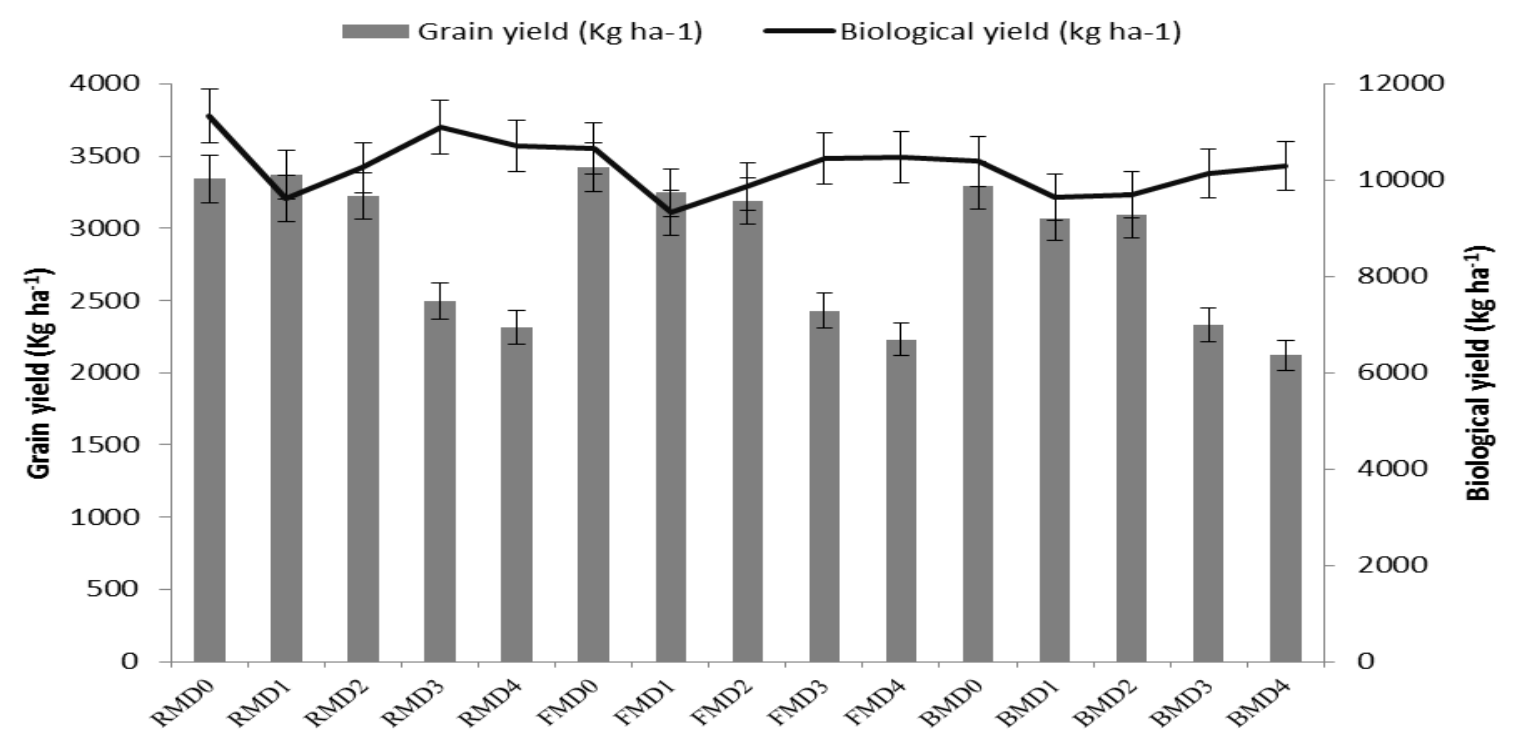

Figure 3. Effect of planting methods and deficit irrigations on grain yield ( $\left.\operatorname{Kg} \mathrm{ha}^{1}\right)$ and biological yield $\left(\mathrm{Kg} \mathrm{ha}^{-1}\right)$ of maize

\section{Conclusion}

In the light of objective of our experiments and the results discussed following conclusion can be drawn. First Deficit irrigation in flowering and grain filling stage seriously affected grain yield of 
maize, while deficit irrigation in vegetative stages not resulted in higher decreased in yield. Second Full irrigation (10 irrigations) give significantly heavier yield components, grain yield and biological yield and third Ridge planting produced maximum yield components, grain yield and biological yield as compared to flat and broadcast planting methods. On the basis of the above results it is recommended that in water scare area grow maize on ridge planting method and give deficit irrigation at vegetative stage (one irrigation missing at six leaves stages) inoder to increased water productivity (Efficiency).

\section{Authors' contributions}

Conceived and designed the experiments: A Sohail, S Ali, S Anwar, Performed the experiments: Manzoor, Analyzed the data: Manzoor, MO Khan, S Nawaz, Contributed materials/ analysis/ tools: FA Shah, I Ali, J Iqbal, J Ahmad, F Ahmad, H Nawaz \& M Kefayatullahm Wrote the paper: Manzoor

\section{References}

1. MNFSR (2014). Agriculture statistics of Pakistan. Govt. of Pakistan. Ministry of national food security and research. Division (Economic wing) Islamabad.

2. Aziz A, Saleem M, Rahman H \& Mohammand F (1992). Genetic variability for yield and disease resistance in full and short season varieties of maize. Sarhad J Agric 8(2): 195-198.

3. Karim I \& Faci JM (2006). Deficit irrigation in maize for reducing agricultural water use in a Mediterranean environment. Agri Water Manag 96(3): 383-394.

4. GOP (2012). Ministry of Food, Agriculture. Economic Wing, Islamabad, Pakistan.

5. Ali MH, Hoque MR, Hassan AA \& Khair A (2007). Effect of deficit irrigation on yield, water productiveity, and economic returns of wheat. Agri Water Manag 92(1): 151-161.

6. Fereres E \& Soriano A (2007). Deficit irrigation for reducing agricultural water use. J Exp Bot 58(2): 147-159.
7. Zhang S \& Oweis M (2008). Effect of irrigation amounts applied with subsurface drip irrigation on corn evapotranspiration, yield, water use efficiency, and dry matter production in a semi-arid climate. Agric Water Manag 95: 895-908.

8. Karrou M, Owei T, Enein RA \& Sherif $M$ (2012). Yield and water productivity of maize and wheat under deficit and raised bed irrigation practices in Egypt. Afric J Agric Res 7(11): 1755-1760.

9. Pereira LS, Owas T \& Aziz A (2008). Irrigation management under water scarcity. Agri Water Manage 57(3): 175206.

10. Khan A, Hoque MR, Hassan AA \& Khair A (2007). Effect of deficit irrigation on yield, water productivity, and economic returns of wheat. Agri Water Manag 92(1): 151-161.

11. Li X, Kang S, Zhang X, Li F \& Lu H (2018). Deficit irrigation provokes more pronounced responses of maize photosynthesis and water productivity to elevated $\mathrm{CO}_{2}$. Agri Water Manag 195: 71-83.

12. Chai Q, Gan Y, Zhao C, Xu HL, Waskom RM, Niu Y \& Siddique KHM (2016). Regulated deficit irrigation for crop production under drought stress. A review. Agron for Sustain Devel 36(1): 3.

13. Jan MT, Shah P, Hollington PA, Khan MJ\& Sohail Q (2009).Agriculture Research: Design and Analysis. A Monograph, Peshawar: Agric. Univ.

14. Gu Z, Qi Z, Ma L \& Yuan S (2017). Water stress based deficit irrigation scheduling using RZWQM2 model for maize in Colorado. In 2017 ASABE Annual International Meeting, pp. 1. American Society of Agricultural and Biological Engineers.

15. Mohammadi SA, Khazaei HR \& Nezami A (2017). Effects $N$ management on maize grain yield and its component under deficit irrigation. Iranian $J$ of Field Crops Res 15(1): 24-33.

16. Memon SQ, Baig MB \& Mari GR (2007). Tillage practices and effect of sowing methods on growth and yield of 
maize crop. Agricultura Tropica ET Subtropica 40: 3.

17. Bakht J, Shafi M, Rehman H, Uddin R \& Anwar S(2011). Effect of planting methods on growth, phenology and yield of maize varieties. Pak $J$ of Bot 43(3): 1629-1633.

18. Ahmadi SH, Mosallaeepour E, KamgarHaghighi AA \& Sepaskhah AR (2015). Modeling maize yield and soil water content with Aqua Crop under full and deficit irrigation managements. Water Res Manag 29(8): 2837-2853.

19. Ma L, Ahuja LR, Islam A, Trout TJ, Saseendran SA \& Malone RW (2017). Modeling yield and biomass responses of maize cultivars to climate change under full and deficit irrigation. Agricultural Water Management. 180: 88-98.

20. Tari AF (2016). The effects of different deficit irrigation strategies on yield, quality, and water-use efficiencies of wheat under semi-arid conditions. Agri Water Manag 167: 1-10.

21. Lopez JR, Winter JM, Elliott J, Ruane AC, Porter C \& Hoogenboom G (2017). Integrating growth stage deficit irrigation into a process based crop model. Agri and Forest Meteorol 243: 84-92.

22. Khan MB, Hussain M, Raza A, Farooq $S$ \& Jabran K (2015). Seed priming with $\mathrm{CaCl}_{2}$ and ridge planting for improved drought resistance in maize. Turkish J of Agri and Forest 39(2): 193-203.

23. Pang B, Zhang K, Kisekka I, Bean S, Zhang M \& Wang D (2018). Evaluating effects of deficit irrigation strategies on grain sorghum attributes and biofuel production. J of Cereal Sci 79: 13-20.

24. Gonzalez MG, Ramos TB, Carlesso R, Paredes P, Petry MT, Martins JD, Aires NP \& Pereira LS (2015). Modelling soil water dynamics of full and deficit drip irrigated maize cultivated under a rain shelter. Biosys Engine 132: 1-18.

25. Golzardi F, Baghdadi A \& Afshar RK (2017). Alternate furrow irrigation affects yield and water-use efficiency of maize under deficit irrigation. Crop and Pasture Sci 68(8): 726-734.

26. Wang J, Tong L, Kang S, Li F, Zhang X, Ding R, Du T \& Li S (2017). Flowering characteristics and yield of maize inbreds grown for hybrid seed production under deficit irrigation. Crop Sci 57(4): 2238-2250.

27. Mahajan G, Sharda R, Kumar A \& Singh KG (2007). Effect of plastic mulch on economizing irrigation water and weed control in baby corn sown by different methods. African J of Agri Res 2(1): 1926.

28. Ha BM (2017). A review of growth stage deficit irrigation affecting sticky maize production.

29. Qamar R \& Khan I (2014). Morphological and phenological attributes of maize affected by different tillage practices and varied sowing methods. American $J$ of Plant Sci 5: 1657-1664.

30. Rudnick D, Irmak S, Ray C, Schneekloth J, Schipanski M, Kisekka I\& Schlegel A (2017). Deficit irrigation management of corn in the high plains: A review. In Proceedings of the 29th Annual Central Plains Irrigation Conference pp. 21-22.

31. Arif M, Ihsanullah, Khan S, Ghani F \& Yousafzai HK (2001). Responce of maize varieties to different planting methods. Sarhad J Agric 17(2): 159-163.

32. Tanveer SK, Hussain I, Sohail M, Kissana NS \& Abbas SG (2003). Effects of different planting methods on yield and yield components of wheat. Asian $J$ Plant Sci 210: 811-813. 